\title{
Optimization of Medical Supply Chains and Forward Store Locations for Recurrent Homecare Patient Demand with Periodic Interruptions
}

\author{
Ram Prashanth Radha Krishnan1, James C. Benneyan ${ }^{1 *}$, Sibel B. Sonuc ${ }^{2}$ \\ ${ }^{1}$ Healthcare Systems Engineering Institute, Northeastern University, Boston, MA, USA \\ ${ }^{2}$ Ozyegin University, Istanbul, Turkey \\ Email: ^j.benneyan@northeastern.edu
}

How to cite this paper: Radha Krishnan, R.P., Benneyan, J.C. and Sonuc, S.B. (2018) Optimization of Medical Supply Chains and Forward Store Locations for Recurrent Homecare Patient Demand with Periodic Interruptions. American Journal of Operations Research, 8, 203-220.

https://doi.org/10.4236/ajor.2018.83012

Received: March 29, 2018

Accepted: May 22, 2018

Published: May 25, 2018

Copyright $\odot 2018$ by authors and Scientific Research Publishing Inc. This work is licensed under the Creative Commons Attribution International License (CC BY 4.0).

http://creativecommons.org/licenses/by/4.0/

(c) $\underset{\mathrm{EY}}{ }$ Open Access

\begin{abstract}
Robust and cost-effective distribution is critical to any home delivery network growing company, both to meet demand under normal conditions and to adapt to temporary disruptions. Home healthcare is anticipated to be a rapidly growing modality of healthcare, itself the largest industry in the US and rife with optimization needs in areas such as logistics, scheduling, and supply chains. We develop two mixed integer programming models to optimize forward storage locations in the supply chain of a national consumable medical supplies company with consistent monthly repeating demand, temporary disruption of facility operations, and remote international manufacturers. Modified $p$-median single and multi-echelon models are used to determine optimal locations of warehouses and distribution facilities that minimize total transportation cost, with $13 \%$ savings in one application (approximately $\$ 1.4$ million annually). Sensitivity analyses to a range of scenarios suggest that the optimal solution is robust across a number of potential scenarios.
\end{abstract}

\section{Keywords}

Facility Location, Medical Supplies, Supply Chain Optimization, Network Analysis

\section{Introduction}

A supply chain that ensures timely delivery is essential to almost all markets, with a recently growing industry segment being home healthcare, or more 
simply homecare. As science progresses and the population ages, an increasing amount of healthcare is being provided in the home by formal and informal caregivers [1] [2]. While generally better in terms of care quality, costs, and patient-centeredness [3], this movement also introduces new logistics complexities, one being timely and efficient coordinated delivery of homecare medical supplies. Given the complexity of such problems, in other industries mathematical models often are used to analyze and optimize locations of manufacturing sites, distribution centers, and forward storage locations relative to demand patterns, volume, and geography (e.g. [4] [5] [6] [7]). We focus here on multi-mode distribution networks for consumable homecare supplies involving repeating monthly home customer demand, transportation via full truck load (FTL), less than truck load (LTL), and couriers, and international or geographically remote manufacturers. Examples within and beyond healthcare include monthly dialysis fluid, pharmaceutical supplies, cosmetics, perishable food supplies, printed periodicals, and others. As an illustration, we apply these models to an international medical supply company under a variety of demand scenarios. The company supplies home dialysis fluid and equipment to several thousand US customer homes on both regular (e.g. recurring) and emergent (e.g. next day) bases.

Facility location and supply chain problems have been investigated in various contexts for decades, with the general aim being to locate one or more warehouses that distribute products across various routes and shipping modalities to all demand locations [8] [9] [10]. Originating with Weber's work to locate a single warehouse that minimizes total distance to several customers [11], early studies often applied a min-max approach to distances between supply and demand points [12], whereas more contemporary studies often focus on minimizing total transportation and opportunity costs. Most problems of this type have essentially five components [13]: 1) locations of suppliers, 2) locations of customers, 3) number of facilities being located, 4) candidate locations for these facilities, and 5) performance metrics to compare alternatives. While cost is the most common criteria [14], others include the number of stages, customer responsiveness and backorders, and inventory levels or ordering size. While much of the literature focuses on optimizing outbound shipments, inbound shipments also often can significantly impact optimal warehouse locations.

This paper develops two types of multi-modal network models, a $p$-median single-echelon model that minimizes the total weighted distance from $p$ storage locations to $k$ customer demand nodes [15] [16] [17] and a hub-and-spoke multi-echelon model that additionally optimizes the location of distribution facilities between warehouses and customers [8] [9] [18] [19] [20]. The remainder of this paper is organized as follows. Section 2 describes the topology and assumptions of the type of distribution networks studied here. Sections $3-5$ describe the two network models developed for this problem, summarizes their results, and conduct several sensitivity analyses. Section 6 discusses general conclusions, insights, and recommendations. 


\section{General Context and Case Study}

The structure of the current supply chain is illustrated in Figure 1, a 1-median network with three basic levels: supplier, warehouse, and demand locations. Products are manufactured at two international locations and sent to a single US warehouse from which they are distributed to home-customers. While monthly demand for each product is known and fairly constant, delivery time windows are narrow and thus can produce high transportation costs. Products are shipped via truck from the warehouse to several forward-storage courier locations close to customers, and which then deliver them to their final destinations. Product demand is fairly stable and time-sensitive, with emergency deliveries periodically shipped directly from the warehouse to end-consumers due to either additional demand or a supply chain disruption.

Figure 2 illustrates the two alternate network structures mentioned above. In other settings, adding a second warehouse tends to be cost efficient whereas more than two often becomes inefficient [21]. Our objective in both models is to determine the optimal number and location of facilities that minimize total transportation cost. Since operational and storage costs are minimal compared to transportation cost, for simplicity they are not considered in either model. To consolidate inbound shipments from manufacturers, only FTL shipments are used, whereas multiple outbound modes (FTL, LTL, courier) are used to distribution facilities, couriers, and customers depending on volume and service level needs. Shipments exceeding 15,000 pounds can be shipped only via FTL but cannot exceed truck capacity of 44,000 pounds.

Figure 3 summarizes current supplier, customer, and potential alternate warehouses and distribution facility locations. Customer demand at each location primarily is deterministic, requiring consistent amounts of consumable

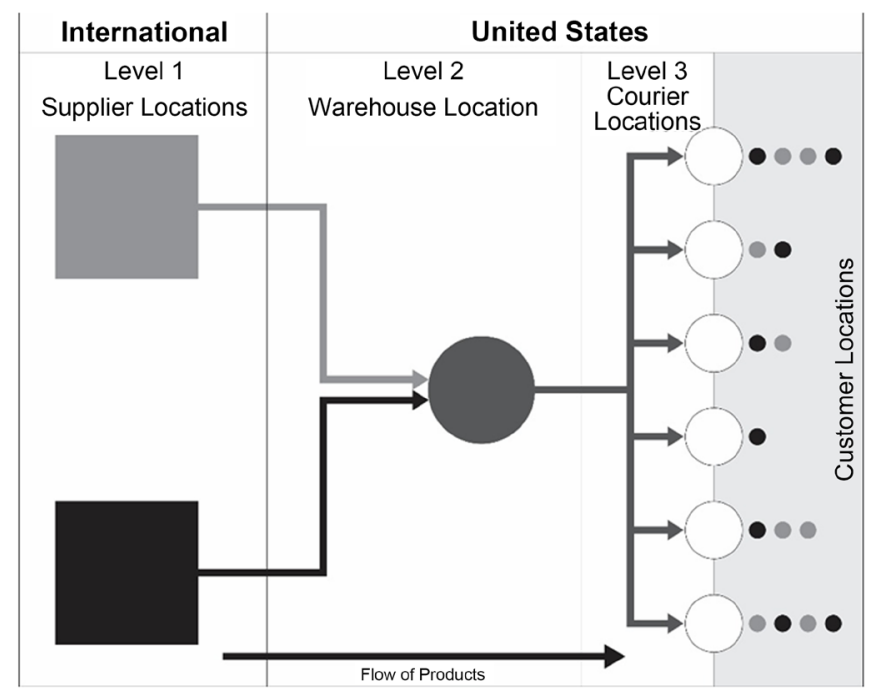

Figure 1. Illustration of general architecture of current supply chain network, with multiple manufacturers supplying a central warehouse that in term forward stores some product near destination couriers and home demand locations. 


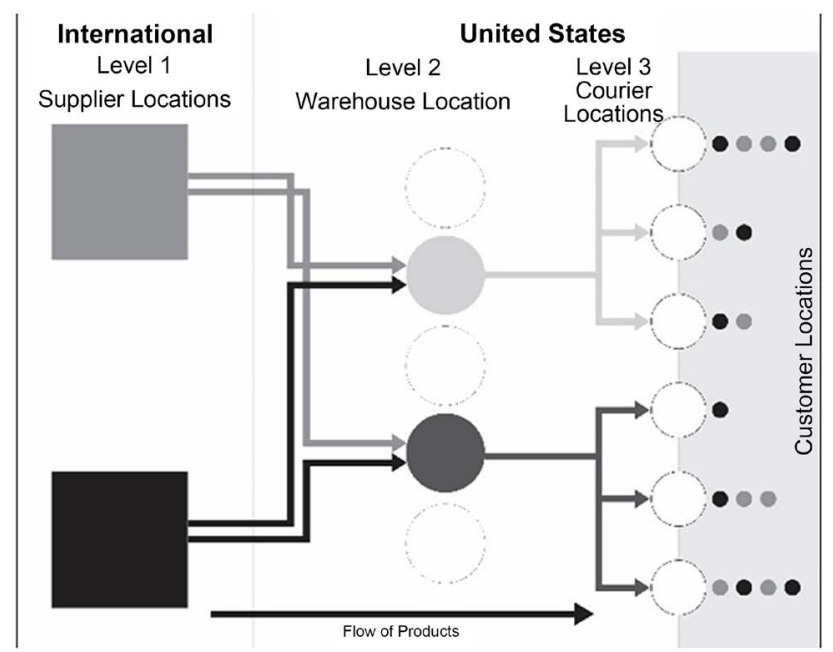

(a)

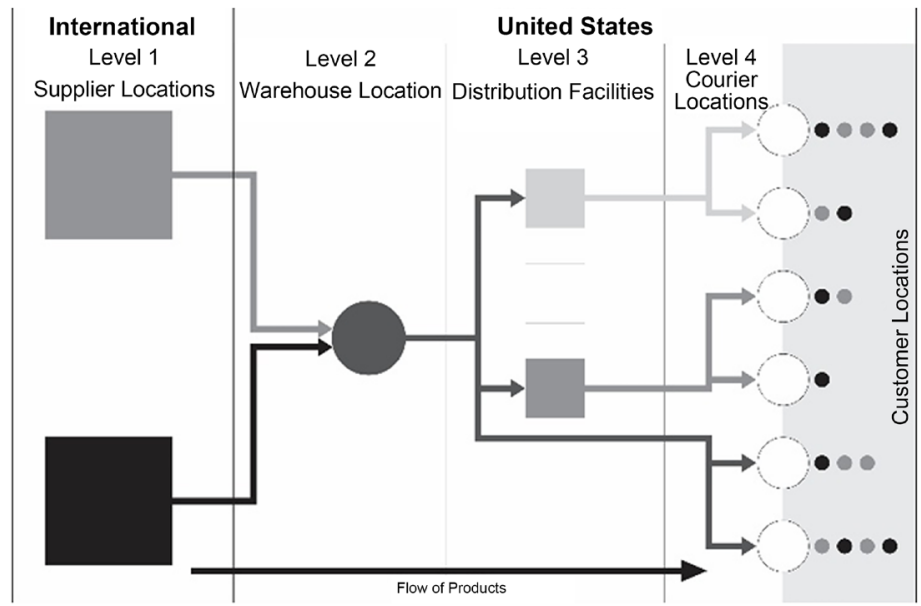

(b)

Figure 2. Alternate supply chain network structures: (a) p-warehouse single-echelon model with multiple central warehouses; (b) Hub-and-spoke multi-echelon model with intermediate distribution facilities.

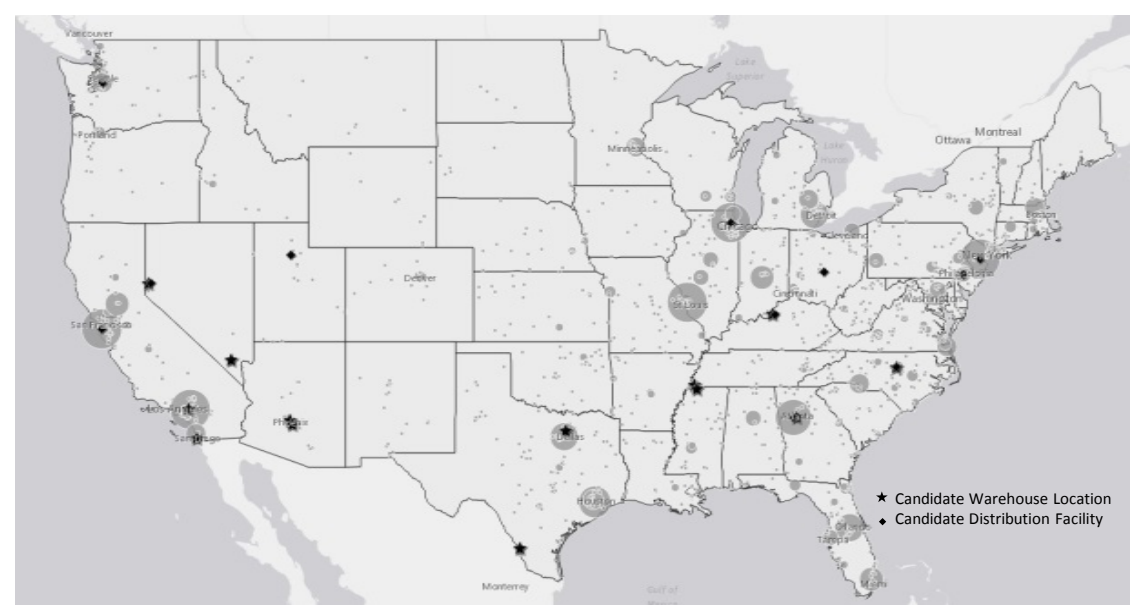

Figure 3. Locations of current and candidate warehouses, distribution facilities, courier locations, and home customers. 
supplies monthly. Product currently is supplied to 151 forward store courier locations and from these delivered to end-customers. For direct shipments to home care patients, 380 locations can be served via LTL and 1699 locations can be served via courier. Emergency shipments are satisfied directly from the warehouse using courier service providers. Twenty-six additional candidate warehouse and distribution facility locations (13 of each) were considered in our models based on geographic feasibility, zoning, and other logistics considerations.

\section{Mathematical Models}

\subsection{P-Warehouse Single-Echelon Model}

Table 1 summarizes parameters and decision variables used to develop a single-echelon optimization model. Given a set of candidate warehouse locations $J$, the binary decision variable $x_{j}=1$ if location $j$ is selected and 0 otherwise. Warehouses can provide shipments of any product $l \in L$, with $f_{j k l}$ denoting outbound shipment quantities of product $l$ from warehouse $j$ to demand location $k$ and $\bar{f}_{i j l}$ denoting inbound quantities of product $l$ to warehouse $j$ from supplier $i$. FTL trucking costs for inbound and outbound shipments, $\bar{c}_{i j}$ and $c_{j k}^{1}$, respectively, are based on distance while the LTL cost $c_{j k}^{2}$ is based on shipment weight. Shipment costs via couriers are denoted by $c_{j k}^{3}$, with the binary variable $y_{j k}=1$ if warehouse $j$ supplies courier location $k$. The decision variables $\bar{t}_{i j}$ and $t_{j k}^{1}$ indicate the number of monthly FTL trucks from manufacturer $i$ to warehouse $j$ and from warehouse $j$ to demand location $k$, respectively. The decision variable $t_{j k}^{2}$ indicates the weight of an LTL shipment from warehouse $j$ to demand location $k$.

Using the above notation, the $p$-median single-echelon model is formulated as:

$$
\begin{aligned}
& \min \left(\sum_{i \in I} \sum_{j \in J}\left(\bar{c}_{i j} * \bar{d}_{i j} * \bar{t}_{i j}\right)+\sum_{j \in J} \sum_{k \in K}\left(c_{j k}^{1} * d_{j k} * t_{j k}^{1}\right)\right. \\
& \left.\sum_{j \in J} \sum_{k \in K}\left(c_{j k}^{2} * t_{j k}^{2}\right)+\sum_{j \in J} \sum_{k \in K}\left(c_{j k}^{3} * y_{j k}\right)\right)
\end{aligned}
$$

s.t.

$$
\begin{gathered}
\sum_{j \in J} x_{j}=n \\
\sum_{k \in K}\left(y_{j k}\right) \geq x_{j} \quad \forall j \\
\sum_{k \in K}\left(y_{j k}\right) \leq x_{j} *|K| \quad \forall j \\
y_{j k} \leq x_{j} \quad \forall j, \forall k \\
\sum_{j \in J} y_{j k} \leq 1 \quad \forall k \\
\sum_{j \in J} f_{j k l} \geq r_{k l} \quad \forall k, \forall l \\
f_{j k l} \leq r_{k l} * y_{j k} \quad \forall j, \forall k, \forall l \\
\bar{f}_{i j l} \leq x_{j} * a_{i l} * \sum_{k \in K} r_{k l} \quad \forall i, \forall j, \forall l
\end{gathered}
$$


Table 1. Notation for parameters and decision variables used in both models.

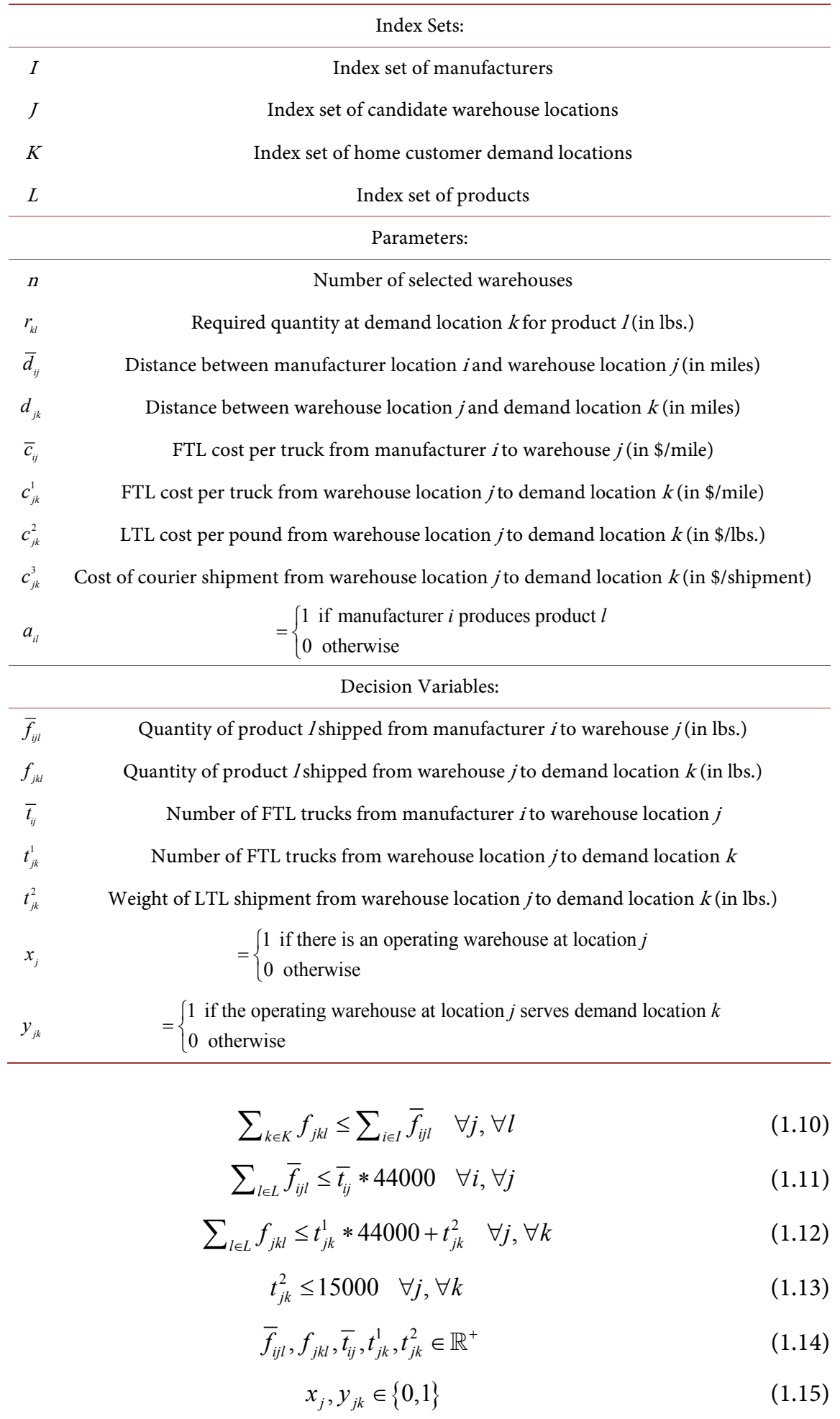

The objective function 1.1 minimizes total inbound and outbound cost, with the first term based on the number of FTL trucks from manufacturers to warehouses, the second term based on the number of FTL trucks from warehouses to demand locations, the third term based on LTL shipment weight from ware- 
houses to demand locations, and the fourth term based on courier costs from warehouses to demand locations. Constraint 1.2 specifies the number of warehouses to use, $n$, while constraints 1.3 and 1.4 ensure only these selected warehouses serve demand locations and that all serve at least one demand location but not more than the total number of demand locations. Constraints 1.5 and 1.6 ensure a shipping route can be used only if the associated warehouse is operating and that each demand location is served by at most one warehouse.

Constraints 1.7 and 1.8 ensure that the total amount of product received by a demand location satisfies demand and that products only ship via open routes. Constraints 1.9 and 1.10 ensure that products shipped to a warehouse come from suppliers who produce them and that the outflow of products from a warehouse does not exceed its inflow. Constraints 1.11 and 1.12 determine the number of inbound and outbound FTL trucks required, as well as the total weight of LTL shipments. Constraint 1.13 limits the capacity of LTL shipments. Constraint 1.14 ensures non-negativity of product flow, number of FTL trucks, and weight of LTL shipments and constraint 1.15 defines decision variables $x_{j}$ and $y_{j k}$ to be binary.

\subsection{Hub-and-Spoke Multi-Echelon Model}

To also include intermediate distribution facilities, some additional notation is needed (Table 2). The term $\tilde{f}_{s k l}$ denotes outbound shipment quantities from distribution facility $s$ to demand location $k$ of product $l$, and $\hat{f}_{j s l}$ denotes inbound shipment quantities from warehouse $j$ to distribution facility $s$ of product 1. The decision variables $\hat{t}_{j s}$ and $\tilde{t}_{s k}^{1}$ indicate the number of FTL trucks from warehouse $j$ to distribution facility $s$ and from distribution facility $s$ to demand location $k$, respectively. The decision variable $\tilde{t}_{s k}^{2}$ indicates the weight of LTL shipments from distribution facility $s$ to demand location $k$. Transportation cost in each of these segments is denoted by $\hat{c}_{j s}, \tilde{c}_{j k}^{1}$, and $\tilde{c}_{j k}^{2}$, respectively, and $\tilde{c}_{j k}^{3}$ denotes the courier cost.

The hub-and-spoke multi-echelon model then is:

$$
\begin{aligned}
& \min \left(\sum_{i \in I} \sum_{j \in J}\left(\bar{c}_{i j} * \bar{d}_{i j} * \bar{t}_{i j}\right)+\sum_{j \in J} \sum_{k \in K}\left(c_{j k}^{1} * d_{j k} * t_{j k}^{1}\right)\right. \\
& +\sum_{j \in J} \sum_{k \in K}\left(c_{j k}^{2} * t_{j k}^{2}\right)+\sum_{j \in J} \sum_{k \in K}\left(c_{j k}^{3} * y_{j k}\right) \\
& +\sum_{j \in J} \sum_{s \in S}\left(\hat{c}_{j s} * \hat{d}_{j s} * \hat{t}_{j s}\right)+\sum_{s \in S} \sum_{k \in K}\left(\tilde{c}_{s k}^{1} * \tilde{d}_{s k} * \tilde{t}_{s k}^{1}\right) \\
& \left.+\sum_{s \in S} \sum_{k \in K}\left(\tilde{c}_{s k}^{2} * \tilde{t}_{s k}^{2}\right)+\sum_{s \in S} \sum_{k \in K}\left(\tilde{c}_{s k}^{3} * \tilde{y}_{s k}\right)\right)
\end{aligned}
$$

s.t.

$$
\begin{gathered}
\sum_{j \in J} x_{j}=n \\
\sum_{s \in S} \tilde{x}_{s}=m \\
\sum_{s \in S} \hat{z}_{j s} \leq m * x_{j} \quad \forall j \\
\tilde{x}_{s} \leq \sum_{j \in J} \hat{z}_{j s} \quad \forall s
\end{gathered}
$$


Table 2. Additional parameters and decision variables used in multi-echelon hub-and-spoke model.

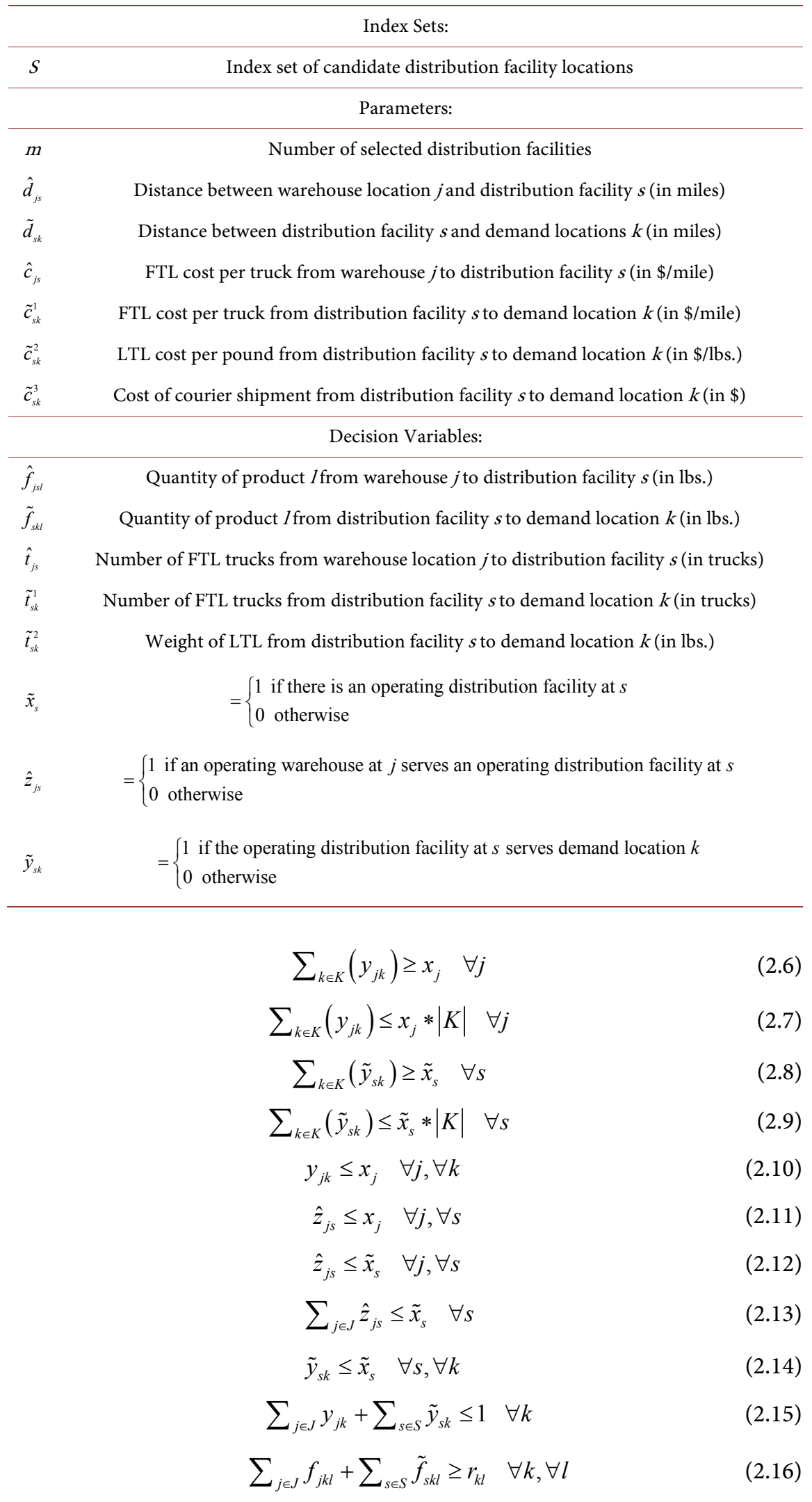




$$
\begin{gathered}
f_{j k l} \leq r_{k l} * y_{j k} \quad \forall j, \forall k, \forall l \\
\tilde{f}_{s k l} \leq r_{k l} * \tilde{y}_{s k} \quad \forall s, \forall k, \forall l \\
\bar{f}_{i j l} \leq x_{j} * a_{i l} * \sum_{k \in K} r_{k l} \quad \forall i, \forall j, \forall l \\
\hat{f}_{j s l} \leq \hat{z}_{j s} * \sum_{k \in K} r_{k l} \quad \forall j, \forall s, \forall l \\
\sum_{k \in K} f_{j k l}+\sum_{s \in S} \hat{f}_{j s l} \leq \sum_{i \in I} \bar{f}_{i j l} \quad \forall j, \forall l \\
\sum_{k \in K} \tilde{f}_{s k l} \leq \sum_{j \in J} \hat{f}_{j s l} \quad \forall s, \forall l \\
\sum_{l \in L} \bar{f}_{i j l} \leq \bar{t}_{i j} * 44000 \quad \forall i, \forall j \\
\sum_{l \in L} f_{j k l} \leq t_{j k}^{1} * 44000+t_{j k}^{2} \quad \forall j, \forall k \\
t_{j k}^{2} \leq 15000 \quad \forall j, \forall k \\
\sum_{l \in L} \hat{f}_{j s l} \leq \hat{t}_{j s} * 44000 \quad \forall j, \forall s \\
\sum_{l \in L} \tilde{f}_{s k l} \leq \tilde{t}_{s k}^{1} * 44000+\tilde{t}_{s k}^{2} \quad \forall s, \forall k \\
\tilde{t}_{s k}^{2} \leq 15000 \quad \forall s, \forall k \\
\bar{f}_{i j l}, f_{j k l}, \hat{f}_{j s l}, \tilde{f}_{s k l}, \bar{t}_{i j}, t_{j k}^{1}, t_{j k}^{2}, \hat{t}_{j s}, \tilde{t}_{s k}^{1}, \tilde{\tilde{t}}_{s k}^{2} \in \mathbb{R}^{+} \\
x_{j}, y_{j k}, \tilde{x}_{s}, \tilde{y}_{s k}, \hat{z}_{j s} \in\{0,1\}
\end{gathered}
$$

The objective function 2.1 minimizes the total transportation cost as previously, but now including inbound and outbound costs for distribution facilities. The first four cost terms are the same as the previously, with the additional fifth term being the transportation cost between warehouses and distribution facilities, and the remaining three terms being the transportation costs from distribution facilities to demand locations based on number of FTL trucks, LTL shipment weights, and courier shipments, respectively. Constraints 2.2 and 2.3 specify the number of warehouses and distribution facilities, while constraints 2.4 and 2.5 ensure that only open warehouses supply distribution facilities and that all distribution facilities are supplied by at least one warehouse.

Constraints 2.6 - 2.9 ensure that only open facilities supply demand locations and that all open facilities supply at least one demand location. Constraints 2.10 and 2.11 ensure possible shipping routes exist only between open warehouses and distribution facilities, while constraint 2.12 allows only one warehouse to supply to each distribution facility. Constraints 2.13 and 2.14 ensure that either a warehouse or a distribution facility serve any particular demand point, constraint 2.15 ensures at most one incoming route to each demand location (either from warehouse or distribution facility), and constraint 2.16 ensures that all customer demand is satisfied. Constraints 2.17 and 2.18 ensure that products ship only across allowed routes.

As previously, constraint 2.19 ensures that shipments to warehouses only come from suppliers that produce that product and constraint 2.20 similarly ensures shipments from warehouses to distribution facilities only through open 
routes. Constraints 2.21 and 2.22 ensure outbound shipments from warehouses and distribution facilities do not exceed their inbound shipments. Constraint 2.23 and 2.24 compute the number of inbound FTL shipments to a warehouse, outbound FTL shipments, and total LTL weight to be shipped via each route. Constraint 2.25 enforces the capacity limit on LTL shipments. Similarly, constraints 2.26 - 2.28 compute FTL shipments and LTL weight for distribution facilities. Constraint 2.29 ensures non-negativity of the number of FTL trucks, LTL shipment weights, and product flow to and from all warehouses and distribution facilities, and constraint 2.30 defines the decision variables $x_{j}, y_{j k}, \tilde{x}_{s}, \tilde{y}_{s k}$ and $\hat{z}_{j s}$ to be binary.

\section{Results}

Both models were implemented in IBM ILOG CPLEX Optimization Studio Version 12.6.0.0 running on a 64-bit Windows 7 computer with Intel Core i7-4770 CPU @ 3.40GHz and 8.00 GB of RAM. Although both types of problems can be difficult to solve, with their computational complexity being of order $0\left(n^{3}\right)$ [22] [23] [24] and thus NP-hard (Kariv and Hakimi, 1979), reasonable run times are obtained in our applications (Table 3). FTL transportation costs are based on distances and historical pricings collected from the internet

(https://www.truckloadrate.com). LTL transportation cost per pound was calculated from an industry standard pricing using the "CzarLite tables", while courier costs were calculated based on route and weight shipments.

Table 3 summarizes results for the single echelon $p$-warehouse network model,

Table 3. Optimization results for $p$-warehouse network analysis.

\begin{tabular}{|c|c|c|c|c|}
\hline & \multicolumn{4}{|c|}{ Number of warehouses } \\
\hline & 1 & 2 & 3 & 4 \\
\hline Warehouse locations & Texas & Texas, California & $\begin{array}{l}\text { Texas, } \\
\text { California, } \\
\text { Kentucky }\end{array}$ & $\begin{array}{c}\text { Texas, } \\
\text { California, } \\
\text { Kentucky, North } \\
\text { Carolina }\end{array}$ \\
\hline $\begin{array}{c}\text { Shipment cost from } \\
\text { manufacturer to warehouse } \\
\text { locations }\end{array}$ & $\$ 271,898$ & $\$ 204,184$ & $\$ 258,566$ & $\$ 276,286$ \\
\hline $\begin{array}{c}\text { Shipment cost from } \\
\text { warehouses to demand } \\
\text { locations }\end{array}$ & $\$ 321,907$ & $\$ 295,999$ & $\$ 252,262$ & $\$ 226,603$ \\
\hline $\begin{array}{l}\text { Emergency shipment cost } \\
\text { from warehouses to demand } \\
\text { locations }\end{array}$ & $\$ 300,855$ & $\$ 320,320$ & $\$ 275,408$ & $\$ 267,275$ \\
\hline Monthly transportation cost & $\$ 894,660$ & $\$ 820,503$ & $\$ 786,236$ & $\$ 770,164$ \\
\hline Savings & - & $\$ 74,157$ & $\$ 108,424$ & $\$ 124,496$ \\
\hline Annual savings & - & $\$ 889,884$ & $\$ 1,301,088$ & $\$ 1,493,952$ \\
\hline$\%$ of savings & - & $8.29 \%$ & $12.12 \%$ & $13.92 \%$ \\
\hline Model run time & $501.03 \mathrm{Sec}$ & $152.19 \mathrm{Sec}$ & 872.37 Sec & $581.14 \mathrm{Sec}$ \\
\hline
\end{tabular}


successively solved setting $p=1,2,3,4$ warehouses, with the first two warehouses located in the southwest and the next two in the southeast. A substantial savings results by increasing the number of warehouses from one to two, with fewer saving beyond that. These results also indicate that warehouse locations depend to a greater extent on the locations of manufacturers than of home customers, with in this case warehouse proximity to the Mexican border being optimal (Figure 4). To improve robustness to short-term facility shutdowns, a second warehouse in California is optimal, producing roughly $\$ 74,000$ savings monthly in transportation cost.

Table 4 and Table 5 summarize results for the multi-echelon model, assuming just one warehouse or multiple warehouses respectively, and for practical purposes using the warehouse locations from the results of model 1 and then finding the optimal number and locations of distribution facilities.

Note that distribution facilities are located more widely across the country and closer to customer home locations than the warehouses (Figure 5). Opening a distribution facility in North Carolina would save $\$ 50,398$ per month, a $5.63 \%$

Table 4. Results for multi-echelon model assuming just one warehouse.

\begin{tabular}{|c|c|c|c|c|c|}
\hline & \multicolumn{5}{|c|}{ Number of distribution facilities } \\
\hline & 0 & 1 & 2 & 3 & 4 \\
\hline Distribution facility locations & - & $\begin{array}{l}\text { North } \\
\text { Carolina }\end{array}$ & $\begin{array}{l}\text { Georgia, } \\
\text { Illinois }\end{array}$ & $\begin{array}{l}\text { Illinois, } \\
\text { Georgia, } \\
\text { North } \\
\text { Carolina }\end{array}$ & $\begin{array}{c}\text { Georgia, } \\
\text { Illinois, North } \\
\text { Carolina, } \\
\text { California }\end{array}$ \\
\hline $\begin{array}{c}\text { Shipment cost from } \\
\text { manufacturer to warehouse } \\
\text { location }\end{array}$ & $\$ 271,898$ & $\$ 271,898$ & $\$ 271,898$ & $\$ 271,898$ & $\$ 271,898$ \\
\hline $\begin{array}{l}\text { Shipment cost from warehouse } \\
\text { to demand locations }\end{array}$ & $\$ 321,907$ & $\$ 194,324$ & $\$ 108,930$ & $\$ 108,930$ & $\$ 58,840$ \\
\hline $\begin{array}{l}\text { Emergency shipment cost from } \\
\text { warehouse to demand locations }\end{array}$ & $\$ 300,855$ & $\$ 170,097$ & $\$ 134,262$ & $\$ 134,175$ & $\$ 108,530$ \\
\hline $\begin{array}{l}\text { Shipment cost from warehouse } \\
\text { to distribution facilities }\end{array}$ & - & $\$ 52,484$ & $\$ 67,440$ & $\$ 75,891$ & $\$ 98,248$ \\
\hline $\begin{array}{l}\text { Shipment cost from } \\
\text { distribution facility to demand } \\
\text { locations }\end{array}$ & - & $\$ 60,265$ & $\$ 121,652$ & $\$ 99,599$ & $\$ 120,915$ \\
\hline $\begin{array}{l}\text { Emergency shipment cost from } \\
\text { distribution facility to demand } \\
\text { locations }\end{array}$ & - & $\$ 95,197$ & $\$ 119,063$ & $\$ 115,144$ & $\$ 133,610$ \\
\hline Monthly transportation cost & $\$ 894,660$ & $\$ 844,265$ & $\$ 823,245$ & $\$ 805,637$ & $\$ 792,041$ \\
\hline Savings & & $\$ 50,395$ & $\$ 71,415$ & $\$ 89,023$ & $\$ 102,619$ \\
\hline Annual savings & & $\$ 604,740$ & $\$ 856,980$ & $\$ 1,068,276$ & $\$ 1,231,428$ \\
\hline$\%$ of savings & & $5.63 \%$ & $7.98 \%$ & $9.95 \%$ & $11.47 \%$ \\
\hline Model run time & $12.53 \mathrm{Sec}$ & $532.26 \mathrm{Sec}$ & $36.63 \mathrm{Sec}$ & $44.98 \mathrm{Sec}$ & $53.63 \mathrm{Sec}$ \\
\hline
\end{tabular}


Table 5. Results for multi-echelon model assuming multiple warehouses.

\begin{tabular}{|c|c|c|c|c|c|c|c|c|c|}
\hline $\begin{array}{l}\text { Number of } \\
\text { warehouses }\end{array}$ & 1 & & & 2 & & & & 3 & \\
\hline $\begin{array}{c}\text { Number of } \\
\text { distribution facilities }\end{array}$ & 0 & 0 & 1 & 2 & 3 & 4 & 0 & 1 & 2 \\
\hline Warehouse locations & Texas & $\begin{array}{l}\text { Texas, } \\
\text { California }\end{array}$ & $\begin{array}{l}\text { Texas, } \\
\text { California }\end{array}$ & $\begin{array}{c}\text { Texas, } \\
\text { California }\end{array}$ & $\begin{array}{l}\text { Texas, } \\
\text { California }\end{array}$ & $\begin{array}{l}\text { Texas, } \\
\text { California }\end{array}$ & $\begin{array}{c}\text { Texas, } \\
\text { California, } \\
\text { Kentucky }\end{array}$ & $\begin{array}{c}\text { Texas, } \\
\text { California, } \\
\text { Kentucky }\end{array}$ & $\begin{array}{c}\text { Texas, } \\
\text { California, } \\
\text { Kentucky }\end{array}$ \\
\hline $\begin{array}{l}\text { Monthly } \\
\text { transportation cost }\end{array}$ & $\$ 894,660$ & $\$ 820,503$ & $\$ 778,010$ & $\$ 754,499$ & $\$ 739,677$ & $\$ 727,684$ & $\$ 786,236$ & $\$ 763,322$ & $\$ 743,129$ \\
\hline Annual savings & - & $\$ 889,884$ & $\$ 1,399,800$ & $\$ 1,681,932$ & $\$ 1,859,796$ & $\$ 2,003,712$ & $\$ 1,301,088$ & $\$ 1,576,056$ & $\$ 1,818,372$ \\
\hline$\%$ of savings & - & $8.29 \%$ & $13.04 \%$ & $15.67 \%$ & $17.32 \%$ & $18.66 \%$ & $12.12 \%$ & $14.68 \%$ & $16.94 \%$ \\
\hline \multicolumn{10}{|c|}{$\begin{array}{r}\$ 1,000,000 \\
\$ 900,000\end{array}$} \\
\hline & & & 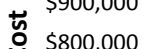 & & & & & & \multirow{7}{*}{\begin{tabular}{|l|} 
Emergency \\
shipments \\
from \\
warehouse \\
ख Warehouse to \\
demand \\
location \\
Manufacturer \\
to warehouse
\end{tabular}} \\
\hline & & & c $\$ 700,000$ & & & & & & \\
\hline & & & $\$ 600,000$ & $\because \because$ & & & & & \\
\hline & & & 횽 $\$ 500,000$ & & & & & & \\
\hline & & & $\sum_{\frac{n}{0}} \$ 400,000$ & & & & & & \\
\hline & & & E $\$ 300,000$ & & & & & & \\
\hline & & & $\stackrel{\mathbb{T}}{\circ} \$ 200,000$ & & & & & & \\
\hline & & & & 1 & $\begin{array}{r}2 \\
\text { Num }\end{array}$ & er of Warehc & ses & 4 & \\
\hline
\end{tabular}

Figure 4. Composition of transportation costs by number of warehouses.

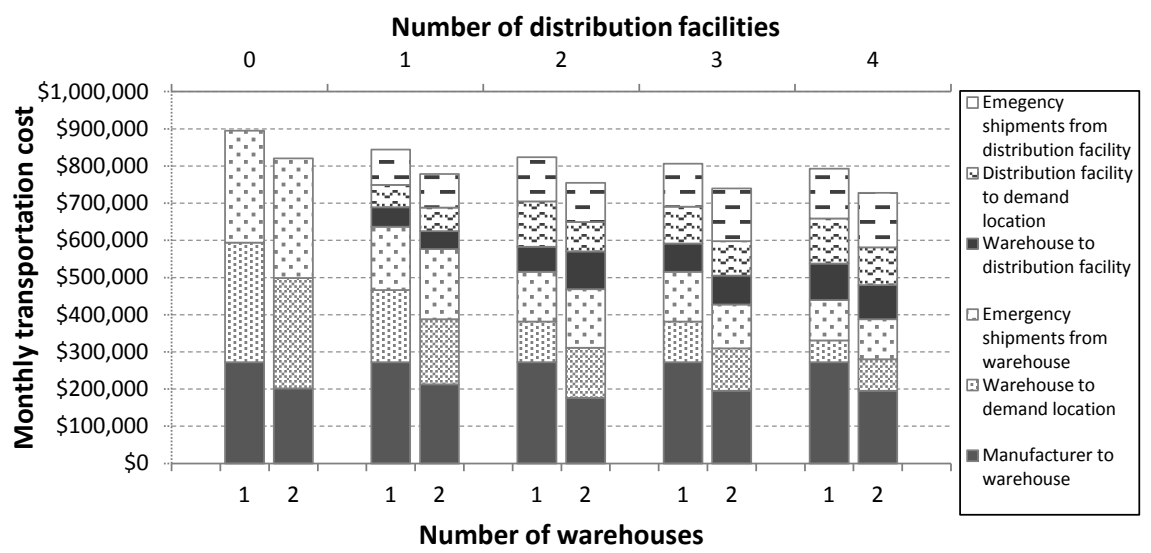

Figure 5. Composition of transportation costs by number of distribution facility (for single-warehouse and two-warehouse networks).

savings, whereas adding two distribution facilities would save an additional $\$ 21,020$ per month. Importantly, additional warehouses both will reduce total 
transportation cost and make the supply chain more robust to temporary failure of facilities. For example, adding a second warehouse for this robustness also reduces costs by $\$ 74,157$ per month, an $8.29 \%$ savings, whereas adding a second warehouse and a distribution facility reduces costs by $\$ 116,650$ per month, a $13 \%$ savings.

\section{Sensitivity Analysis}

Two types of sensitivity analyses were conducted to investigate the effect of geographical changes in demand and the effect of short-term facility shut downs due to weather events or other factors. In the first case, the current demand pattern has $51 \%$ of customers located in the eastern US, $27 \%$ in the western region, and $22 \%$ in the central and mountain regions. As a somewhat extreme-case analysis, Figure 6 and Table 6 summarize optimization results if all demand instead was shifted entirely to either the eastern or western regions of the country. Interestingly, the optimal location of the first warehouse remains unchanged for

Table 6. Impact of changes in customer locations on optimal network. (a) Single-echelon network; (b) One-warehouse multi-echelon network; (c) Two-warehouse multi-echelon network.

(a)

\begin{tabular}{|c|c|c|c|c|c|c|c|c|}
\hline \multirow[b]{2}{*}{$\begin{array}{l}\text { Number of } \\
\text { warehouses }\end{array}$} & \multicolumn{4}{|c|}{ Demand evenly spread on the east coast } & \multicolumn{4}{|c|}{ Demand evenly spread on the west coast } \\
\hline & 1 & 2 & 3 & 4 & 1 & 2 & 3 & 4 \\
\hline $\begin{array}{l}\text { Warehouse } \\
\text { location }\end{array}$ & Texas & $\begin{array}{c}\text { Texas, } \\
\text { Kentucky }\end{array}$ & $\begin{array}{c}\text { Texas, } \\
\text { Kentucky, } \\
\text { North Carolina }\end{array}$ & $\begin{array}{l}\text { Texas, Kentucky, } \\
\text { North Carolina, } \\
\text { Georgia }\end{array}$ & Texas & $\begin{array}{c}\text { Texas, } \\
\text { California }\end{array}$ & $\begin{array}{c}\text { Texas, } \\
\text { California, } \mathrm{Ne}- \\
\text { vada }\end{array}$ & $\begin{array}{l}\text { Texas, } \\
\text { California, } \\
\text { Nevada, } \\
\text { Arizona }\end{array}$ \\
\hline $\begin{array}{c}\text { Monthly } \\
\text { transportation } \\
\text { cost }\end{array}$ & $\$ 874,560$ & $\$ 832,230$ & $\$ 812,169$ & $\$ 800,663$ & $\$ 926,568$ & $\$ 592,351$ & $\$ 573,400$ & $\$ 565,524$ \\
\hline Model run time & $12.37 \mathrm{Sec}$ & $545.04 \mathrm{Sec}$ & $72.322 \mathrm{Sec}$ & $612.772 \mathrm{Sec}$ & $12.09 \mathrm{Sec}$ & $45.942 \mathrm{Sec}$ & $370.518 \mathrm{Sec}$ & $99.013 \mathrm{Sec}$ \\
\hline
\end{tabular}

(b)

\begin{tabular}{|c|c|c|c|c|c|c|c|c|c|c|}
\hline $\begin{array}{c}\text { Warehouse } \\
\text { location }\end{array}$ & & & Texas & & & & & Texas & & \\
\hline $\begin{array}{l}\text { Number of } \\
\text { distribution } \\
\text { facilities }\end{array}$ & 0 & 1 & 2 & 3 & 4 & 0 & 1 & 2 & 3 & 4 \\
\hline $\begin{array}{c}\text { Distribution } \\
\text { facility } \\
\text { location }\end{array}$ & - & $\begin{array}{c}\text { North } \\
\text { Carolina }\end{array}$ & $\begin{array}{l}\text { Ohio, North } \\
\text { Carolina }\end{array}$ & $\begin{array}{l}\text { Georgia, } \\
\text { Ohio, North } \\
\text { Carolina }\end{array}$ & $\begin{array}{l}\text { Georgia, Ohio, } \\
\text { North } \\
\text { Carolina, } \\
\text { Pennsylvania }\end{array}$ & - & $\begin{array}{l}\text { Southern } \\
\text { California }\end{array}$ & $\begin{array}{l}\text { Southern } \\
\text { California, } \\
\text { Northern } \\
\text { California }\end{array}$ & $\begin{array}{c}\text { Southern } \\
\text { California, } \\
\text { Northern } \\
\text { California, } \\
\text { Washington }\end{array}$ & $\begin{array}{c}\text { Southern } \\
\text { California, } \\
\text { Northern } \\
\text { California, } \\
\text { Georgia, } \\
\text { Washington }\end{array}$ \\
\hline $\begin{array}{c}\text { Monthly } \\
\text { transportation } \\
\text { cost }\end{array}$ & $\$ 874,560$ & $\$ 816,062$ & $\$ 794,030$ & $\$ 776,992$ & $\$ 764,154$ & $\$ 926,568$ & $\$ 882,811$ & $\$ 864,463$ & $\$ 849,589$ & $\$ 837,879$ \\
\hline $\begin{array}{l}\text { Model run } \\
\text { time }\end{array}$ & $12.43 \mathrm{Sec}$ & $569.75 \mathrm{Sec}$ & $28.66 \mathrm{Sec}$ & $55.55 \mathrm{Sec}$ & $49.37 \mathrm{Sec}$ & $12.26 \mathrm{Sec}$ & $36.07 \mathrm{Sec}$ & $24.07 \mathrm{Sec}$ & $43.32 \mathrm{Sec}$ & $41.70 \mathrm{Sec}$ \\
\hline
\end{tabular}


(c)

\begin{tabular}{|c|c|c|c|c|c|c|c|c|c|c|}
\hline $\begin{array}{l}\text { Warehouse } \\
\text { locations }\end{array}$ & \multicolumn{5}{|c|}{ Texas, California } & \multicolumn{5}{|c|}{ Texas, California } \\
\hline $\begin{array}{l}\text { Number of } \\
\text { distribution } \\
\text { facilities }\end{array}$ & 0 & 1 & 2 & 3 & 4 & 0 & 1 & 2 & 3 & 4 \\
\hline $\begin{array}{c}\text { Distribution } \\
\text { facility } \\
\text { location }\end{array}$ & - & $\begin{array}{c}\text { North } \\
\text { Carolina }\end{array}$ & $\begin{array}{c}\text { Pennsylvania, } \\
\text { Nevada }\end{array}$ & $\begin{array}{l}\text { Pennsylvania, } \\
\text { Ohio, Nevada }\end{array}$ & $\begin{array}{c}\text { Georgia, } \\
\text { Pennsylvania, } \\
\text { Ohio, Nevada }\end{array}$ & - & Washington & $\begin{array}{c}\text { Northern } \\
\text { California, } \\
\text { Washington }\end{array}$ & $\begin{array}{l}\text { Northern } \\
\text { California, } \\
\text { Washington, } \\
\text { Utah }\end{array}$ & $\begin{array}{c}\text { Northern } \\
\text { California } \\
\text { Washington, } \\
\text { Utah, } \\
\text { Nevada }\end{array}$ \\
\hline $\begin{array}{c}\text { Monthly } \\
\text { transportation } \\
\text { cost }\end{array}$ & $\$ 867,749$ & $\$ 821,181$ & $\$ 780,316$ & $\$ 760,594$ & $\$ 746,593$ & $\$ 592,351$ & $\$ 576,732$ & $\$ 564,828$ & $\$ 560,281$ & $\$ 558,872$ \\
\hline $\begin{array}{l}\text { Model run } \\
\text { time }\end{array}$ & $15.83 \mathrm{Sec}$ & $914.59 \mathrm{Sec}$ & $914.85 \mathrm{Sec}$ & $376.48 \mathrm{Sec}$ & 375.57 Sec & $15.65 \mathrm{Sec}$ & $615.08 \mathrm{Sec}$ & $283.81 \mathrm{Sec}$ & $614.83 \mathrm{Sec}$ & $374.57 \mathrm{Sec}$ \\
\hline
\end{tabular}
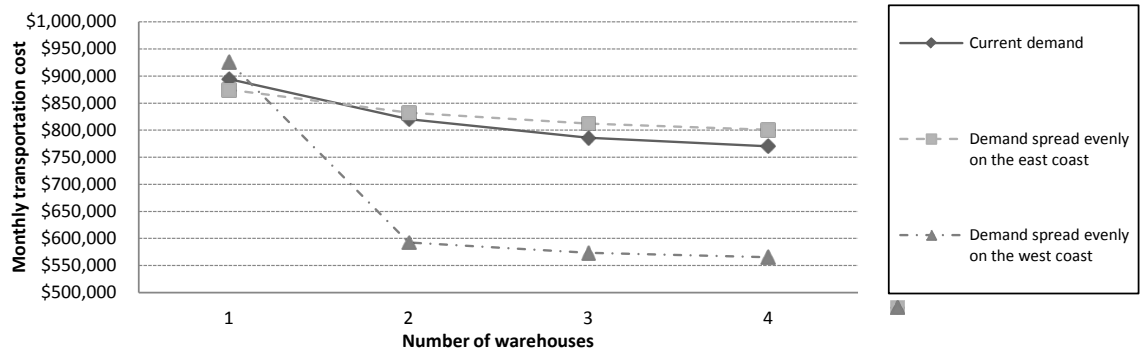

(a)

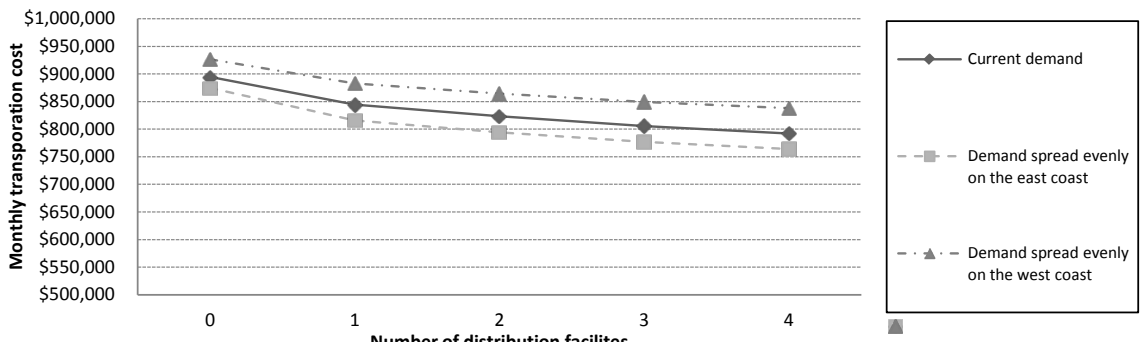

(b)

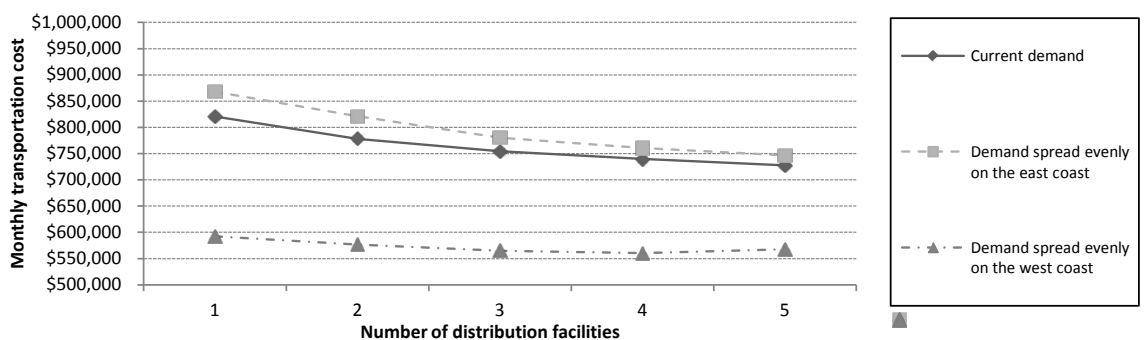

(c)

Figure 6. Impact of customer location on monthly transportation cost. (a) Single-echelon; (b) Single-warehouse multi-echelon; (c) Two-warehouse multi-echelon.

all single and multi-echelon models and scenarios, but with second and third warehouses now concentrating closer to customer demand in the respective region. Cost savings from additional warehouses or distribution facilities also sig- 
nificantly increases as the demand shifts to the west coast.

Conversely, Table 7 summarizes the cost impact if demand changes but instead the original optimal locations still are used (i.e., without re-optimization). As shown, the original optimal locations remain optimal for roughly $30 \%$ of demand redistribution scenarios, although costs increase by roughly $4 \%$ if demand shifts to the east coast and 7\% if the demand shifts to the west coast.

As a second sensitivity analysis, we analyzed transportation costs if one or more facilities are unable to ship product for a short period of time (e.g., one month) such as due to weather, stock outs, or operational issues. We assumed a "worse case" shut down scenario of one month and that other facilities can deliver products to customers if and when this occurs (except when only $p=1$ warehouse). Table 8 summarizes the change in costs if either one or two warehouses fail, with each number of warehouses being optimal when all facilities are operating. As shown, costs significantly increase when the warehouse in Texas fails in a 2 -warehouse network but much less so in a 3-warehouse network. Although a second warehouse less significantly reduces outbound cost, overall transportation cost therefore favors locating a second warehouse in California.

For the three-warehouse single-echelon network, there is a savings of $\$ 108,424$ per month over a one-warehouse network, or $\$ 1.3$ million (12\%) annually, as well as improvement in network stability. For the multi-echelon case,

Table 7. Change in cost for optimal network under change in demand.

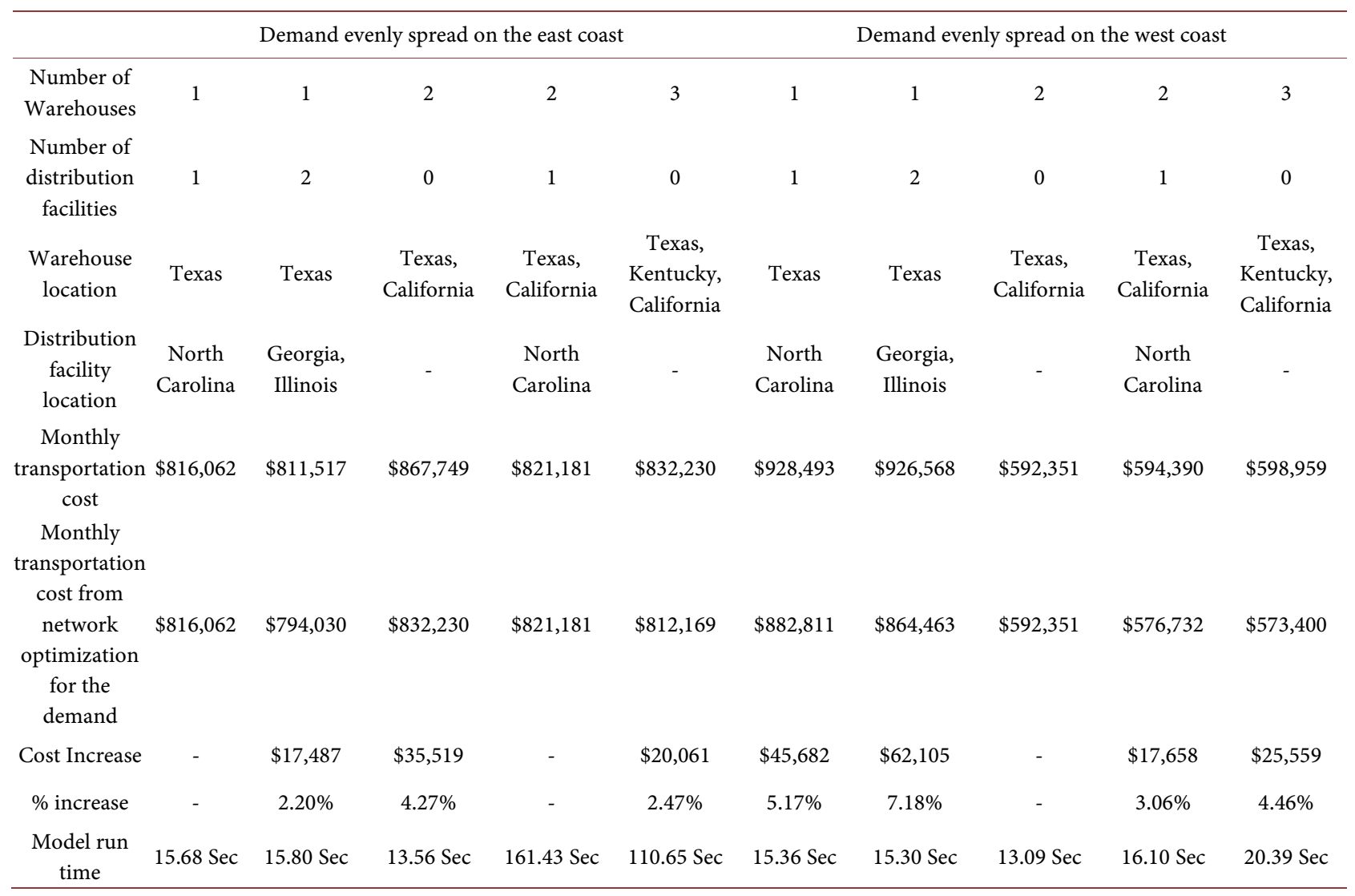


Table 8. Facility failure analysis: (a) Single-echelon network; (b) Multi-echelon network.

(a)

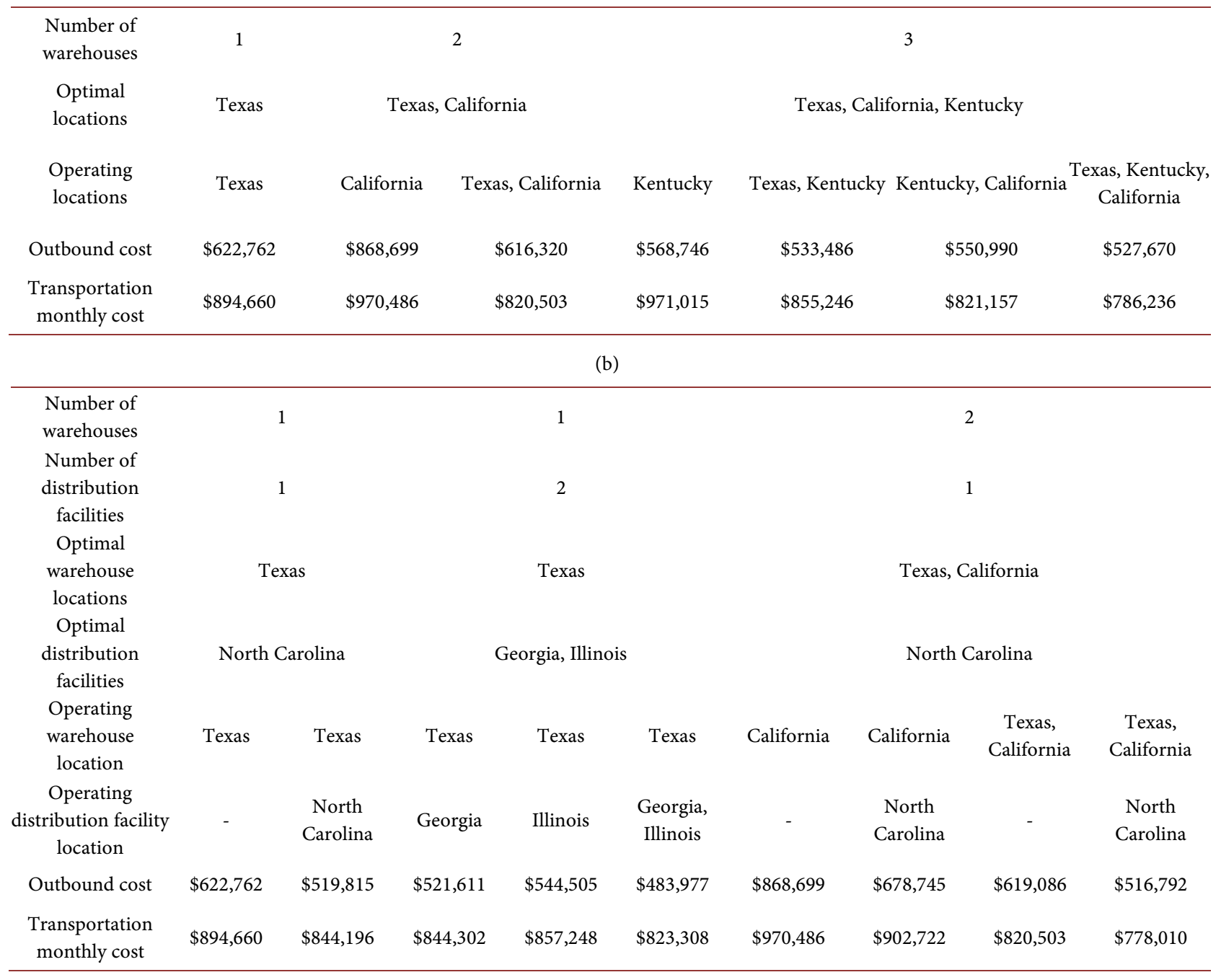

the two-warehouse network with one distribution facility tends to be optimal both under regular and facility failure scenarios, producing a monthly savings of $\$ 116,650$ (13\%), or $\$ 1.4$ million annually, as compared to a one-warehouse network.

\section{Discussion}

Optimal supply chains can significantly affect transportation costs and profit margins [5]. Two network structures for a homecare medical supply distribution network were analyzed in this paper in order to minimize total cost and provide protection against temporary facility shutdowns. The remote locations of manufacturers have greater influence on the network structure than the end-customers, with a significant reduction in total transportation cost if two warehouses are used. More than one distribution facility shows marginal savings, however, due to the substantial increase in transportation cost from warehouses. 
In our case, one additional warehouse and one distribution facility saves approximately $13 \%$ in total transportation cost, or roughly $\$ 1.4$ million annually. Although additional facilities continue to produce a bit more savings, operational and inventory management costs likely will increase as well. Recall that we focused only on transportation cost since it comprises roughly $80 \%$ of total logistics cost in this case, rather than also including inventory and operational costs. We also assume no trans-shipment between facilities [25] and that shipping routes have no capacity constraints, in essence equating to unbounded truck company availability, which seems reasonable.

\section{Acknowledgements}

The authors thank Hande Musdal for assistance with model formulation and Catarina Smith for assistance with manuscript preparation.

\section{References}

[1] Gutiérrez, E.V., Gutiérrez, V. and Vidal, C.J. (2013) Home Health Care Logistics Management: Framework and Research Perspectives. International Journal of Industrial Engineering and Management, 4, 173-182.

[2] Liu, R., Xie, X. and Garaix, T. (2013) Weekly Home Health Care Logistics. 201310 th IEEE International Conference on Networking, Sensing and Control, Evry, 10-12 April 2013, 282-287.

[3] Cryer, L., Shannon, S.B., Van Amsterdam, M. and Leff, B. (2012) Costs for "Hospital at Home" Patients Were 19 Percent Lower, with Equal or Better Outcomes Compared to Similar Inpatients. Health Affairs, 31, 1237-1243. https://doi.org/10.1377/hlthaff.2011.1132

[4] Baumol, W. and Wolfe, P. (1958) A Warehouse-Location Problem. Operations Research, 6, 252-263. https://doi.org/10.1287/opre.6.2.252

[5] Melkote, S. and Daskin, M.S. (2001) An Integrated Model of Facility Location and Transportation Network Design. Transportation Research Part A: Policy and Practice, 35, 515-538. https://doi.org/10.1016/S0965-8564(00)00005-7

[6] Nagurney, A. (2010) Optimal Supply Chain Network Design and Redesign at Minimal Total Cost and with Demand Satisfaction. International Journal of Production Economics, 128, 200-208. https://doi.org/10.1016/j.ijpe.2010.07.020

[7] SteadieSeifi, M., Dellaert, N.P., Nuijten, W., Van Woensel, T. and Raoufi, R. (2014) Multimodal Freight Transportation Planning: A Literature Review. European Journal of Operational Research, 233, 1-15. https://doi.org/10.1016/j.ejor.2013.06.055

[8] Campbell, J.F. (1994) Integer Programming Formulations of Discrete Hub Location Problems. European Journal of Operational Research, 72, 387-405. https://doi.org/10.1016/0377-2217(94)90318-2

[9] Marianov, V., Serra, D. and ReVelle, C. (1999) Location of Hubs in a Competitive Environment. European Journal of Operational Research, 114, 363-371. https://doi.org/10.1016/S0377-2217(98)00195-7

[10] O'Kelly, M.E. (1987) A Quadratic Integer Program for the Location of Interacting Hub Facilities. European Journal of Operational Research, 32, 393-404. https://doi.org/10.1016/S0377-2217(87)80007-3 
[11] Weber, A. and Friedrich, C.J. (1929) Alfred Weber's Theory of Location of Industries. The University of Chicago Press, Chicago.

[12] Dearing, P.M. and Francis, R.L. (1974) A Minimax Location Problem on a Network. Transportation Science, 8, 333-343. https://doi.org/10.1287/trsc.8.4.333

[13] ReVelle, C.S. and Eiselt, H.A. (2005) Location Analysis: A Synthesis and Survey. European Journal of Operational Research, 165, 1-19. https://doi.org/10.1016/j.ejor.2003.11.032

[14] Beamon, B.M. (1998) Supply Chain Design and Analysis: Models and Methods. International Journal of Production Economics, 55, 281-294. https://doi.org/10.1016/S0925-5273(98)00079-6

[15] Bozkaya, B., Zhang, J. and Erkut, E. (2002) An Efficient Genetic Algorithm for the p-Median Problem. Springer-Verlag, Berlin, 179-205. https://doi.org/10.1007/978-3-642-56082-8_6

[16] Hakimi, S.L. (1964) Optimum Locations of Switching Centers and the Absolute Centers and Medians of a Graph. Operations Research, 12, 450-459. https://doi.org/10.1287/opre.12.3.450

[17] Hansen, P. and Mladenović, N. (1997) Variable Neighborhood Search for the p-Median. Location Science, 5, 207-226. https://doi.org/10.1016/S0966-8349(98)00030-8

[18] Cheong, M.L.F., Bhatnagar, R. and Graves, S.C. (2007) Logistics Network Design with Supplier Consolidation Hubs and Multiple Shipment Options. Journal of Industrial and Management Optimization, 3, 51-69. https://doi.org/10.3934/jimo.2007.3.51

[19] Goldman, A.J. (1969) Optimal Locations for Centers in a Network. Transportation Science, 3, 352-360.

[20] Skorin-Kapov, D., Skorin-Kapov, J. and O’Kelly, M. (1996) Tight Linear Programming Relaxations of Uncapacitated $p$-Hub Median Problems. European Journal of Operational Research, 94, 582-593. https://doi.org/10.1016/0377-2217(95)00100-X

[21] Fotheringham, A. and O'Kelly, M.E. (1989) Spatial Interaction Models: Formulations and Applications. Kluwer Academic Publishers, Dordrechit.

[22] Goldman, A.J. (1971) Optimal Center Location in Simple Networks. Transportation Science, 5, 212-221. https://doi.org/10.1287/trsc.5.2.212

[23] O’Kelly, M.E., Bryan, D., Skorin-Kapov, D. and Skorin-Kapov, J. (1996) Hub Network Design with Single and Multiple Allocation: A Computational Study. Location Science, 4, 125-138. https://doi.org/10.1016/S0966-8349(96)00015-0

[24] Kariv, O. and Hakimi, S. (1979) An Algorithmic Approach to Network Location Problems. II: The p-Medians. SIAM Journal on Applied Mathematics, 37, 539-560. https://doi.org/10.1137/0137041

[25] Hansen, P., Peeters, D. and Thisse, J.F. (1983) Public Facility Location Models: A Selective Survey. Locational Analysis of Public Facilities, Amsterdam, 223-262. 